1-бөлім

Математика
Раздел 1

Математика
Section 1

Mathematics

UDC 005

\author{
Akhmetova A.Zh. ${ }^{1 *}$, La L.L. ${ }^{1}$ \\ ${ }^{1}$ Faculty of Information technologies, Eurasian National University, Republic of Kazakhstan, \\ Astana \\ *E-mail: akhmetova_azh@enu.kz
}

\title{
About the group approach in the task of fuzzy synthetic evaluation
}

The fuzzy synthetic evaluation method can be applied to problems where we need to evaluate object determined by various heterogeneous features. The problem is to determine quantitatively significances of various features th6666/at is their weights. Using various weight vectors leads to the different results of evaluation. There are various methods to define weight vectors but there is no criterion to determine the best of them. The work is devoted to the problem of determining the balance in the method of fuzzy synthetic evaluation sites. The paper proposes the use of the cluster approach to determine the weights of the criteria which in a sense, a universal and can be applied to various modifications of this method. We establish a connection between the fuzzy synthetic evaluation method and fuzzy classifications and propose a group approach to determine weights of the method. Also, the article describes the proof of the theorem, which determines the weight of the criteria for the group approach.

Key words: the synthetic method, a group approach, the weight criteria, fuzzy classification.

Ахметова А.Ж., Ла. Л.Л.

\section{О групповом подходе в задаче нечеткой синтетической оценки}

Синтетический метод нечеткой оценки может быть применен к задачам, в которых нужно оценить объект, определяемый различными разнородными функциями. Проблема состоит в том, чтобы определить значения различных функций, которым является количественная характеристика - их вес. Использование различных весовых векторов приводит к различным результатам оценки. Существуют различные методы для определения весовых векторов, но нет никакого критерия, чтобы определить лучшие из них. В методе нечеткой синтетической оценки объектов можно определить веса. Предлагается использование группового подхода, с помощью которого можно определить веса критериев. Он является универсальным и может быть применен к различным модификациям этого метода. Для определения веса метода установлена связь между синтетическим методом оценки и нечеткой классификации. Кроме того, в статье описывается доказательство теоремы, которая определяет вес критериев для группового подхода.

Ключевые слова: синтетический метод, групповой подход, веса критериев, нечеткая классификация. 


\title{
Ахметова А.Ж., Ла. Л.Л. \\ Бұлдыр синтетикалық бағалау есебіндегі топтық әдіс туралы
}

\begin{abstract}
Бұлдыр бағалауды жүзеге асыратын синтетикалық әдісті түрлі функциялармен сипатталатын объекттерді бағалауға мүмкіндік беретін есептерге қолдануға болады. Мұндай есептердегі негізгі мәселе - сандық сипаттама болып табылатын түрлі функциялардың мәндері, яғни олардың салмағын анықтау болып табылады. Түрлі салмақтық векторларды қолдану бағалаудың түрлі нәтижелеріне алып келеді. Салмақтық векторларды анықтаудың түрлі әдістері болғанымен, олардың ішінен ең тиімдісін таңдап беретін критерийлердің жоқтың қасы. Объекттерді бұлдыр синтетикалық бағалау әдісі арқылы салмақты анықтауға мүмкіндік бар. Критерийлердін салмағын анықтауға мүмкіндік беретін топтық есептеуді қолдану ұсынылуда. Ол универсалды жол болып саналады және оны синтетиклық бағалау әдісінің түрлі модификацияларына қолдануға болады. Сонымен қатар әдістің салмағын анықтау мақсатында бағалаудың синтетикалық әдісі мен бұлдыр классификациялау әдісі арасында байланыс орнатылды. Бұдан бөлек мақалада топтық есептеуге арналған критерийлер салмағын анықтайтын теорема дәлелдеуі сипатталады.
\end{abstract}

Түйін сөздер: синтетикалық әдіс, топтық есеп, критерийлер салмағы, бұлдыр классификация.

\section{Introduction}

This article is devoted to an application of the group approach for solution of an object evaluation problem where the object is described by numerous non homogeneous attributes. The group approach is used to determine the weights in the fuzzy synthetic evaluation method and a theorem that allows us to find the corresponding weights of the group solution is proved. The fuzzy synthetic evaluation method can be applied to numerous problems where we need to evaluate object determined by many heterogeneous features. Examples include assessment of fire safety in buildings, river and ground water quality [1-3],[9], evaluation of seismic safety of buildings, road transport congestion, air pollution [4-8], [10] and so on. We propose to use a group approach for determining weights which is in some sense universal and can be applied to various modifications of the fuzzy synthetic evaluation method.

Let's remind the definition of the fuzzy synthetic evaluation method and define necessary auxiliary concepts and notations.

Let $M=\left\{S_{1}, \ldots, S_{h}\right\}$ be a finite set of evaluated objects. When an object $S \in M$ is the vector $S=\left(s_{1}, \ldots, s_{n}\right) \in R^{n}$ of dimension $n$, we say that $S$ is described by $n$ features or attributes. The magnitude $s_{i}$ expresses the quantitative value of $i$-th feature of the object $S$. In applications attributes characterize various properties of an object that are measured in different units. For example, a roll of fabric $S=\left(s_{1}, s_{2}, s_{3}\right)$ can be determined by three features: width, length of the roll and the price for 1 meter of fabric.

As a result of applying the fuzzy synthetic evaluation method we get object's evaluation that is equal to one of the $m$ values of natural language. For example, the evaluation of fire safety of building can accept one of the values: very safe building, safe, medium, not safe, dangerous. That is after applying of the method the object will be evaluated to belong to one of 5 classes of buildings.

Let $L=\left\langle\left\{a_{1}, \ldots, a_{m}\right\},<\right\rangle$ be a finite lattice, where $a_{i}<a_{j}$ iff $i<j$.

Definition 1 [11]. A fuzzy subset $A$ of the set $M$ is a map

$$
\mu_{A}: M \rightarrow L
$$


Here $M$ is a set of evaluated objects and the value $\mu_{A}(S)$ is interpreted as the degree of membership of an element $S$ to the fuzzy set $A$, in our case, we suppose that $\mathrm{S}$ with a degree of $\mu_{A}(S)$ possesses the evaluated property. The task of assessment of $S \in M$ will consist in determination of $\mu_{A}(S)$. Definition of $\mu_{A}(S)$ happens at some stages called model levels. Depending on quantity of levels we will distinguish one, two, etc. level models.

We suppose that $a_{i}$ accept values of the natural language, expressing some quality, for example, good, bad, etc.

Now we proceed to the description of the method applied to the two-level model.

Assume that there are $k$ factors $\Phi_{1}, \ldots, \Phi_{k}$ on which the object will be evaluated. Each factor is described by $n_{t}, t=1, \ldots, k$, attributes. Let's consider how an object is evaluated for factor $\Phi_{t}$.

In the initial phase, with respect to each attribute, object belongs to one of $m$ classes that corresponds to $a_{j}, j=1, \ldots, m$. Object's belonging to one of the classes is defined as follows.

Let's determine the matrix $\mathbf{R}^{t}=\left(r_{i j}^{t}\right)_{n_{t} \times m}$ by the following way.

Let $s_{i} \in J_{i}=\left[y_{i 1}, y_{i, m+1}\right] \subseteq R, i=1, \ldots, n$ and $\left[y_{i 1}, y_{i, m+1}\right]$ be partitioned into $m$ intervals

$$
\left[y_{i 1}, y_{i 2}\right),\left[y_{i 2}, y_{i 3}\right), \ldots,\left[y_{i m}, y_{i, m+1}\right] \text {. }
$$

The values $y_{i 2}, y_{i 3}, \ldots, y_{i m}$ and the functions $\mu_{J_{i}}: J_{i} \rightarrow L$ such that $\mu_{J_{i}}\left(s_{i}\right)=a_{j}$ iff $s_{i} \in$ $\left[y_{i j}, y_{i, j+1}\right)$ are defined by experts of subject's domain of the solved problem. We suppose that the functions $\mu_{J_{i}}$ are either increasing or decreasing i.e. $\mu_{J_{i}}(a) \leq \mu_{J_{i}}(b)$, whereas $a \leq b$ (or $\mu_{J_{i}}(a) \geq \mu_{J_{i}}(b)$ at $a \leq b$ ) Then if $\mu_{J_{i}}$ increases the values $r_{i j}^{t}$ are defined as follows:

$$
r_{i, j}^{t}=\left\{\begin{array}{lr}
\frac{s_{i}-y_{i j}}{y_{i, j+1}-y_{i j}}, & \text { if } \mu_{J_{i}}\left(s_{i}\right)=a_{j} ; \\
0, & \text { otherwise. }
\end{array}\right.
$$

Similarly, if $\mu_{J_{i}}$ is decreasing then

$$
r_{i j}^{t} s=\left\{\begin{array}{lc}
\frac{y_{i j}-s_{i}}{y_{i j}-y_{i, j+1}}, & \text { if } \mu_{J_{i}}\left(s_{i}\right)=a_{j} \\
0, & \text { otherwise }
\end{array}\right.
$$

The first level of the fuzzy synthetic evaluation method is described by equation

$$
\left(\mathbf{w}^{t}\right)^{\prime} \mathbf{R}^{t}=\mathbf{b}^{t}
$$

where $\mathbf{w}^{t}=\left(w_{1}^{t}, \ldots, w_{n_{t}}^{t}\right), 0 \leq w_{i}^{t} \leq 1$, is a weight vector, $\mathbf{b}^{t}=\left(b_{1}^{t}, \ldots, b_{m}^{t}\right)$, the vector $\left(\mathbf{w}^{t}\right)^{\prime}$ is the transpose of $\mathbf{w}^{t}$,

$$
b_{j}^{t}=\sum_{i=1}^{n_{t}} w_{i}^{t} r_{i j}^{t}
$$

$j=1, \ldots . m$. We call $\mathbf{b}^{t}=\left(b_{1}^{t}, \ldots, b_{m}^{t}\right)$ the evaluation vector. On each level, starting from the second one, factors of the prior acts as attributes of the current level We now describe 
the second level of the fuzzy synthetic evaluation method. On the first level we estimated the object $S \in M$ with $n_{t}$ attributes in each of the factors $\Phi^{t}, t=1, \ldots, k$ we used.Let

$$
\mathbf{b}^{t}=\left(\mathbf{w}^{t}\right)^{\prime} \mathbf{R}^{t}
$$

be equations determined on the first level of the method in factors $\Phi^{t}$, where $\mathbf{w}^{t}=$ $\left(w_{1}^{t}, \ldots, w_{n_{t}}^{t}\right)$ is the vector composed of the weights of its attributes, $\mathbf{R}^{t}$ is a matrix composed of the values of the membership function $\mu_{i j}^{t}, \mathbf{R}^{t}=\left(r_{i j}^{t}\right)_{n_{t} \times m}, r_{i j}^{t}=\mu_{i j}^{t}, \mathbf{b}^{t}=\left(b_{1}^{t}, \ldots, b_{m}^{t}\right)$ is the evaluation vector on the first level of the method. Let $\mathbf{B}=\left(b_{t j}\right)_{k \times m}$,

$$
b_{t j}=b_{j}^{t}=\sum_{i=1}^{n_{t}} w_{i}^{t} r_{i j}^{t}
$$

$t=1, \ldots, k, j=1, \ldots, m$. Then the second level of the fuzzy synthetic evaluation method is described by equation

$$
\mathbf{c}=\mathbf{W}^{\prime} \mathbf{B}
$$

where $\mathbf{W}=\left(W_{1}, \ldots, W_{k}\right)$ is a weight vector on the second level, $W_{t}$ is a weight of the factor $\Phi_{t}, \mathbf{c}=\left(c_{1}, \ldots, c_{m}\right), c_{j}=\sum_{t=1}^{k} W_{t} b_{t j}$ is the evaluation vector on the second level. Analogously, the fuzzy synthetic evaluation can be determined on the higher levels. Let $\mathbf{c}=\left(c_{1}, \ldots, c_{m}\right)$ be an evaluation vector on the last level of the fuzzy synthetic evaluation method, $\tilde{c}$ is positive integer closest to $\sum_{j=1}^{m} j c_{j}$. Then object $S$ will be estimated by a linguistic meaning that corresponds to an element $a_{\tilde{c}}$ of lattice or in other words, we assume that it belongs to $\tilde{c}$-th class.

\section{A correspondence between fuzzy synthetic evaluations and fuzzy classifications}

In this section the accordance between the fuzzy synthetic evaluation method and fuzzy classifications is established. It's shown that the application of the method to the set of objects will result in a fuzzy classification of these objects. Let's remind the definition of fuzzy classification. Denote

$$
V_{h}^{m}=\left\{A \mid A=\left(a_{i j}\right)_{h \times m}, \quad 0 \leq a_{i j} \leq 1, \quad \sum_{j=1}^{m} a_{i j}=1 ; i=1, \ldots, h\right\} .
$$

Definition 2 [1]. Each matrix $A_{K} \in V_{h}^{m}$ defines a fuzzy classification $K$ of the set $M=$ $\left\{S_{1}, \ldots, S_{h}\right\}$ on $m$ classes. Elements $a_{i j}$ of the matrix $A_{K}$ are interpreted as the membership degree of $S_{i}$ in the $j$-th class. We say that classification $K$ is given by matrix $A_{K}$ and that matrix $A_{K}$ determines classification $K$. The $j$-th class is a fuzzy set determined by the membership function $\mu_{j}\left(S_{i}\right)=a_{i j}$. We call a vector $\mathbf{x}=\left(x_{1}, \ldots, x_{n}\right)$ normal if

$$
\sum_{j=1}^{m} x_{j}=1
$$


Any vector with positive components can be normalized by dividing each component by the sum of all components. On the each level of the fuzzy synthetic evaluation method we get an evaluation vector $\mathbf{b}=\left(b_{1}, \ldots, b_{m}\right)$. Denote by $\mathbf{b}^{N}$ its normalization, that is $\mathbf{b}^{N}=\left(b_{1}^{N}, \ldots, b_{m}^{N}\right)$, where

$$
b_{i}^{N}=b_{i} / \sum_{j=1}^{m} b_{j} .
$$

Let $M=\left\{S_{1}, \ldots, S_{h}\right\}$ be the set of objects to be evaluated, $\mathbf{b}_{i}$ be the normal evaluation vector of $S_{i}, i=1, . ., h$ on some level. Then the matrix composed of these vectors

$$
B_{K}=\left(\begin{array}{c}
\mathbf{b}_{1} \\
\ldots \\
\mathbf{b}_{h}
\end{array}\right)=\left(b_{i j}\right)_{h \times m}
$$

is the matrix of fuzzy classification of the set $M=\left\{S_{1}, \ldots, S_{h}\right\}$, here $b_{i j}$ is $j$-th element of $\mathbf{b}_{i}$. The element $b_{i j}$ expresses the membership degree of the object $S_{i}$ in the $j$-th class.

Proposition 1. Let $\left(\mathbf{b}^{t}\right)^{N}=\left(b_{1}^{t}, \ldots b_{m}^{t}\right), t=1, \ldots, k$, be the normal evaluation vector of the object $S$ in the factor $\Phi_{t}$ on the $l$-th level. $\mathbf{w}=\left(w_{1}, \ldots, w_{k}\right)$ is the normal weight vector, where $w_{t}$ is the weight of the factor $\Phi_{t}$. Let $\mathbf{c}=\left(c_{1}, \ldots, c_{m}\right)$ be an evaluation vector on the level $l+1$. Then

$$
\sum_{j=1}^{m} c_{j}=1
$$

Proof. Let $\mathbf{B}$ be a matrix composed of the vectors $\left(\mathbf{b}^{t}\right)^{N}, t=1, \ldots, k, \mathbf{B}=\left(b_{t j}\right)_{k \times m}$; $b_{t j}=b_{j}^{t}$ is the $j$-th component of the vector $\left(\mathbf{b}^{t}\right)^{N}$. Then

$$
\mathbf{c}=\mathbf{w}^{\prime} \mathbf{B}=\left(\sum_{t=1}^{k} w_{t} b_{t 1}, \ldots, \sum_{t=1}^{k} w_{t} b_{t m}\right) .
$$

Let's find the sum of the component of the vector $\mathbf{c}$.

$$
\sum_{j=1}^{m} c_{j}=\sum_{j=1}^{m}\left(\sum_{t=1}^{k} w_{t} b_{t j}\right)=\sum_{t=1}^{k} w_{t}\left(\sum_{j=1}^{m} b_{t j}\right)=\sum_{t=1}^{k} w_{t} \cdot 1=1 .
$$

Thus, by normalizing the evaluation vectors and weight vectors in each factor on the first level, we will have normal evaluation vectors on the next levels. Accordingly, if on some level of the fuzzy synthetic evaluation method for each of the factors we have fuzzy classification of the evaluated objects represented by the matrix $B_{K}$ then on the next level the matrix composed of evaluation vectors of the $S_{i} i=1, . ., h$ also will be the matrix of fuzzy classification of the set $M=\left\{S_{1}, \ldots, S_{h}\right\}$.

\section{Group approach to determine the weights}

When we use the fuzzy synthetic evaluation method, it is an important task to determine quantitatively significances of various criteria that is their weights. Usually the weights are defined by experts, using the various weight vectors leads to the different results of evaluation. 
There are many methods to define weight vectors but there is no criterion to determine the best of them. In this section the group approach is proposed to determine the weights. The essence of this approach is to determine an evaluation vector that is the closest to the evaluation vectors obtained by using different weight vectors. We will call it the group evaluation vector. The weight vector corresponding to the group evaluation vector is the required one.

Let's define the group evaluation vector which is modification of the definition of the group classification[1]. Group evaluation vectors and corresponding weight vectors will be determined separately on each level. For definiteness, we consider the procedure of finding a group decision on the second level of the fuzzy synthetic evaluation method. Group solutions on the first, third, etc. levels are determined in a similar way. Note that on the first level we consider the group evaluation vector for every factor.

We will denote by $\mathbf{c}(\mathbf{w})$ the evaluation vector obtained on the second level as a result of application the fuzzy synthetic evaluation method with the weight vector $\mathbf{w}=\left(w_{1}, \ldots, w_{k}\right)$. Let $X$ be the set of all weight vectors, $\mathbf{c}(X)=\{\mathbf{c}(\mathbf{x}): \mathbf{x} \in X\}$ be the set of evaluation vectors for all weight vectors from $X$.

Definition 3. Let $\mathbf{c}\left(\mathbf{w}_{1}\right), \ldots, \mathbf{c}\left(\mathbf{w}_{r}\right)$ are evaluation vectors obtained on the second level by applying the fuzzy synthetic evaluation method to the object $S$ by using different weight vectors $\mathbf{w}_{1}, \ldots, \mathbf{w}_{r}$. We call $\mathbf{c}^{*}$ a group evaluation vector for $\mathbf{c}\left(\mathbf{w}_{1}\right), \ldots, \mathbf{c}\left(\mathbf{w}_{r}\right)$ if the minimum of the functional

$$
F(\mathbf{c})=\sum_{p=1}^{r} \rho^{2}\left(\mathbf{c}\left(\mathbf{w}_{p}\right), \mathbf{c}\right)
$$

is attained on this vector, i.e.

$$
F\left(\mathbf{c}^{*}\right)=\min _{\mathbf{c} \in \mathbf{c}(X)} \sum_{p=1}^{r} \rho^{2}\left(\mathbf{c}\left(\mathbf{w}_{p}\right), \mathbf{c}\right)
$$

Lemma. Let $h_{1}, \ldots, h_{r}$ be arbitrary real numbers, $x=\left(\sum_{i=1}^{r} h_{i}\right) / r$. Then

$$
\sum_{i=1}^{r}\left(x-h_{i}\right)^{2} \leq \sum_{i=1}^{r}\left(y-h_{i}\right)^{2}
$$

for any real $y$.

Proof. We have

$$
\begin{aligned}
& \sum_{i=1}^{r}\left(x-h_{i}\right)^{2}=r x^{2}-2 x\left(h_{1}+\ldots+h_{r}\right)+\sum_{i=1}^{r} h_{i}^{2}=r x^{2}-2 r x^{2}+\sum_{i=1}^{r} h_{i}^{2}, \\
& \sum_{i=1}^{r}\left(y-h_{i}\right)^{2}=r y^{2}-2 y\left(h_{1}+\ldots+h_{r}\right)+\sum_{i=1}^{r} h_{i}^{2}=r y^{2}-2 y r x+\sum_{i=1}^{r} h_{i}^{2} .
\end{aligned}
$$


Assume that for some $y$

$$
\sum_{i=1}^{r}\left(x-h_{i}\right)^{2}>\sum_{i=1}^{r}\left(y-h_{i}\right)^{2}
$$

then

$$
r x^{2}-2 r x^{2}>r y^{2}-2 y r x
$$

or

$$
0>y^{2}-2 y x+x^{2}=(y-x)^{2} .
$$

The last inequality is impossible, the contradiction proves the lemma.

The next theorem allows us to find the weight vector corresponding to the group evaluation vector.

Theorem. Let $\mathbf{c}_{1}, \mathbf{c}_{2}, \ldots, \mathbf{c}_{r}$ be the evaluation vectors obtained on the second level of the fuzzy synthetic evaluation method by $r$ different ways, $\mathbf{w}_{1}, \mathbf{w}_{2}, \ldots, \mathbf{w}_{r}$ be corresponding weight vectors, $\mathbf{c}_{p}=\left(c_{1}^{p}, \ldots, c_{m}^{p}\right), \mathbf{c}_{p}=\mathbf{c}\left(\mathbf{w}_{p}\right), p=1, \ldots, r$. Let $\mathbf{c}^{*}$ be the group evaluation vector for $\mathbf{c}_{1}, \mathbf{c}_{2}, \ldots, \mathbf{c}_{r}, \rho$ be the Euclidean metric. Then the components of the weight vector $\mathbf{w}^{*}=$ $\left(w_{1}^{*}, \ldots, w_{k}^{*}\right)$ corresponding to $\mathbf{c}^{*}$ are determined by the following formula

$$
w_{i}^{*}=\left(\sum_{p=1}^{r} w_{i}^{p}\right) / r, \quad i=1, \ldots, k .
$$

Proof. For the group evaluation vector $\mathbf{c}^{*}=\left(c_{1}^{*}, \ldots, c_{m}^{*}\right)$ we have

$$
F\left(\mathbf{c}^{*}\right)=\min _{\mathbf{c} \in \mathbf{c}(X)} \sum_{p=1}^{r} \rho^{2}\left(\mathbf{c}_{p}, \mathbf{c}\right)=\min _{\mathbf{c} \in \mathbf{c}(X)} \sum_{p=1}^{r}\left(\sqrt{\sum_{j=1}^{m}\left(c_{j}^{p}-c_{j}\right)^{2}}\right)^{2}=\min _{\mathbf{c} \in \mathbf{c}(X)} \sum_{j=1}^{m} \sum_{p=1}^{r}\left(c_{j}^{p}-c_{j}\right)^{2},
$$

where $c=\left(c_{1}, \ldots, c_{m}\right)$. By Lemma the group evaluation vector $\mathbf{c}^{*}=\left(c_{1}^{*}, \ldots, c_{m}^{*}\right)$ is defined as follows

$$
c_{j}^{*}=\left(\sum_{p=1}^{r} c_{j}^{p}\right) / r, j=1, \ldots, m .
$$

Let's show that $\mathbf{w}^{*}$ is a weight vector for $\mathbf{c}^{*}$, i.e. Then

$$
\begin{aligned}
& c_{j}^{*}=\left(\sum_{p=1}^{r} c_{j}^{p}\right) / r=\left(\sum_{p=1}^{r}\left(\sum_{i=1}^{k} w_{i}^{p} b_{i j}\right)\right) / r=\left(\sum_{i=1}^{k}\left(\sum_{p=1}^{r} w_{i}^{p} b_{i j}\right)\right) / r= \\
& \sum_{i=1}^{k} b_{i j}\left(\sum_{p=1}^{r} w_{i}^{p}\right) / r=\sum_{i=1}^{k} b_{i j} w_{i}^{*}= \\
& \sum_{i=1}^{k} w_{i}^{*} b_{i j} .
\end{aligned}
$$


So,

$$
\mathbf{c}^{*}=\left(\mathbf{w}^{*}\right)^{\prime} \mathbf{B} .
$$

The theorem is proved.

Note that if $\mathbf{w}_{p}, \mathbf{c}_{p}=\mathbf{c}\left(\mathbf{w}_{p}\right), p=1, \ldots, r$ are normal vectors then $c^{*}$ and $w^{*}$ are normal vectors too.

\section{Conclusion}

Fuzzy synthetic evaluation method can be applied to problems of estimation of objects is determined by many heterogeneous criteria and factors. The paper proposes the use of the cluster approach to determine the weights of criteria, which in some sense universal and can be applied to various modifications of this method. The article established a connection between the method of fuzzy synthetic evaluation and fuzzy classification, proved the theorem that determines the weight of the criteria for the group approach.

\section{References}

[1] Averkin, A. N., Batyrshin, I. Z., Blishun, A. F., Silov,V. B., Tarasov V.B. Fuzzy Sets in Methods of Control and Artificial Intelligence. - Moscow: Nauka, 1986.

[2] Bohui Pang, Shizhen Bai. An integrated fuzzy synthetic evaluation approach for supplier selection based on analytic network process // Journal of Intelligent Manufacturing. Volume 24, Issue 1, 2013, - pp.163-174.

[3] Chang, Ni-Bin, Chen, H. W., Ning, S. K. Identification of river water quality using the Fuzzy Synthetic Evaluation approach //Journal of Environmental Management. -(2001). - 63(3), - pp.293-305.

[4] Fachao Li, Wenfang Wang, Yan Shi2 and Chenxia Jin. Fuzzy synthetic evaluation model based on the knowledge system // International Journal of Innovative Computing: Information and Contro. Volume 9, - Number 10, - October, 2013, pp.4073-4084.

[5] Gao, Z., Zhong, Q., An, M. Fuzzy Integration Method of Synthetic Evaluation for Traffic and Transportation Systems //Proceedings of the Second International Conference on Transportation and Traffic. Studies -2000, - pp.211-223.

[6] Gorai A. K., Kanchan , Upadhyay A., Goyal P. Design of fuzzy synthetic evaluation model for air quality assessment. // Environment Systems and Decisions. Volume 34, Issue 3, - September, 2014 - pp 456-469.

[7] Hu, B. Q., Lo, S. M., Liu, M., Zhao, C. M. On the Use of Fuzzy Synthetic Evaluation and Optimal Classification for Fire Risk Ranking of Buildings //Neural Computing and Application -2009, - 2, - pp.113-127.

[8] Khan F, Sadiq R. Risk-based prioritization of air pollution monitoring using fuzzy synthetic evaluation technique //Environ Monit Assess. - Jun, 2005, - 105(1-3), - pp.261-83

[9] Sudhir Dahiya, Bupinder Singh, Shalini Gaur, V.K. Garg, H.S. Kushwaha Analysis of groundwater quality using fuzzy synthetic evaluation //Journal of Hazardous Materials. Volume 147, Issue 3, - 2007, - pp.938-946

[10] Tesfamaraim, S., Saatcioglu, M. Seismic Risk Assessment of RC Buildings Using Fuzzy Synthetic Evaluation //Journal of Earthquake Engineering. -2008, - 12(7), -pp.1157-1184.

[11] Zadeh, L. A. Fuzzy sets and their application to pattern classification and clustering analysis. //Fuzzy sets, fuzzy logic, and fuzzy systems. -1996, - pp.355-393. 